\title{
"To Be or Not to Be an Auctioneer?" \\ Some Thoughts on the Legal Nature of Online "eBay" Auctions and the Protection of Consumers
}

\section{Dr Christine Riefa*}

\begin{abstract}
This paper discusses the legal classification of online "eBay" auctions. The discussion has key implications on the scope of consumer protection law as sale by auctions are, for example, excluded from the scope of the Consumer Protection (Distance Selling) Regulations 2000. The paper uncovers that online "eBay" auctions cannot always be considered as traditional auctions and that eBay, as an intermediary, is not to be considered as an auctioneer. This creates difficulties associated with a distributive application of consumer protection laws such as the Consumer Protection (Distance Selling) Regulations 2000. Another set of difficulties is associated with a lenient legal regime applicable to the liability of eBay under the Electronic Commerce (EC Directive) Regulations 2002 . The paper concludes that there is an urgent need to clarify the legal classification of online auctions and to rethink the liability of online auction sites to better protect consumers.
\end{abstract}

Online auctions, auctions, eBay, consumer, consumers, distance selling, electronic commerce.

\section{Introduction}

Auctions can be traced back to 500BC where Babylonian women of marriageable age would be sold to the most generous bidder (Harvey \& Meisel, 2006. p. 4, n¹.05). Although the "goods" nowadays available for sale do no longer include women, the popularity of the auction process as a method of sale has grown steadily across the centuries. Whilst, for many years the auction has been reserved for a handful of specialist people present in the auction room, the evolution of technology such as

\footnotetext{
*Brunel Law School, Christine.Riefa@brunel.ac.uk
} 
telephone, television and more recently the Internet has brought the auction process within the grasp of the general public.

Today the popularity of online auctions for the sale of everyday items is unprecedented. Perhaps the most noted of online auction sites is eBay, which counts in the UK as many as 10 million registered users and 212 million registered users in the world, reporting in the first quarter of 2006 net revenues in excess of $\$ 1.44$ billion. ${ }^{1}$

Whilst one cannot deny the immense success of online auctions and their clear popularity with the public, a small, yet, well-documented series of risks for consumers also mars such success. Those risks range from items being sold, not corresponding to their description to the sale of defective products. Another growing difficulty relates to the sale of fake goods and the growing numbers of scams. Indeed, Internet scams fraud trends published by the Internet Fraud Watch Information Centre in the USA, for January to December 2005, show that auctions complaints for goods being never delivered or misrepresented topped the rankings with $42 \%$ of complaints and an average loss of $\$ 1,155$. In addition, the Federal Trade Commission's figures for 2006 show that Internet auctions are ranked number two of the top 10 consumer complaints categories, behind identity theft. In the UK, recent research also shows that complaints for sales going wrong on online auction sites are on the up (OFT Market Study, 2007).

Yet, despite an important volume of complaints, when things go wrong, the current legal set-up adopted by eBay and other similar sites, leaves consumers with no direct recourse against the site and, in situations where indelicate sellers have disappeared, often with no recourse at all.

This article will attempt to determine what is the current legal landscape for consumers buying on online auction sites and assess how this landscape is protecting consumers. In order to do so, we must first analyse the legal classifications of auctions conducted on online auction sites (1).

Clause 3 of eBay's User Agreement indicates: "eBay is not an auctioneer. Although commonly referred to as an online auction web site it is important to realise that we are not a traditional auctioneer. Instead the site acts as a venue, which allows

1 Figures for the third quarter 2006, available online: http://investor.ebay.com/, [31/10/2006]. 
registered users to offer, sell and buy just about anything which is legal, at any time, from anywhere, in a variety of price formats (...). We do not review listing provided by users, we never possess the items offered through the site and we are not involved in transactions between buyer and sellers." It would appear therefore, that despite the use of a common terminology, not all sale processes described as auctions are actually to be classified as such in the eyes of the law. Since there is no statutory definition of what constitutes an auction in the traditional sense in England or at EU level, there are some difficulties in determining if online auctions are to be considered in the same light as traditional auctions.

This is however an important question as online auction sites of the "eBay type" have evolved from a consumer-to-consumer market place, where individuals would exchange or buy and sell collectables, and where consumer protection law is not applicable, to sites where small and medium enterprises as well as big corporations sell their products to consumers using auction processes. It is on the latter of those relationships, professional to consumer (B2C) that this article will mostly focus. Therefore from the perspective of consumer protection, defining the true legal nature of online auctions takes a critical turn. We are no longer faced with transactions taking place between parties theoretically of equal strength but are entering the core of consumer law policy: the protection of the weaker party. The necessity of an unambiguous legal nature being uncovered is reinforced by the fact that online auctions involve consumers developing contractual relationships with, not one, but two professionals in many instances. First, the consumer will contract with the auction site itself, agreeing to its terms and conditions of use. Second, the consumer will contract with third parties using the site to offer items for sale. In addition, since the auction takes place at a distance, the consumer is not in a position to inspect the goods he or she is bidding for, and, in the most intricate of situation, the consumer will be dealing with a third party established in another jurisdiction.

The traditional English law of auctions does not afford specific protection to consumers. For example, "membership of a professional body is not obligatory, and there are no compulsory accounting rules designed to protect consumers." (Harvey \& Meisel, 2006, p. 13, $\left.\mathrm{n}^{\circ} 1\right)$. Also in some instances consumers are excluded from protection altogether. For example, s.12 (2) of the Unfair Contract Terms Act 1977 states that on a sale by auction or by competitive tender the buyer is not in any circumstances to be regarded as dealing as a consumer. As Harvey and Meisel (2006, 
p. $\left.17, \mathrm{n}^{\circ} 1.40\right)$ note, "the question arises whether auctions conducted wholly virtually over the Internet really are auctions properly so-called. The question is important because the answer may determine whether consumer protections not available to the buyer at auction will be available to the buyer. Thus the applicability of the Unfair Contract terms Act 1977 and the Consumer Protection (Distance Selling) Regulations 2000 (...) may turn on this."

On the other hand, the Electronic Commerce Directive 2000/31/EC of 8 June 2000 implemented in the UK by the Electronic Commerce (EC Directive) Regulations 2002, was adopted in order to reinforce trust in "e-commerce" and encourage the development of online transactions. The Directive creates a legal framework destined to provide free access to the online market whilst, imposing some obligations destined, in theory, to protect consumers more efficiently. Placing online auctions within the scope of the Electronic Commerce (EC Directive) Regulations 2002 may therefore provide a more efficient protection. To do so, one has to determine if online auction sites are to be classified as information society services (2).

\section{Online "eBay" Auctions v. Traditional Auctions}

At first glance, traditional auctions and online auctions display many similarities in the processes employed to conclude the sale, but the mechanisms upon which some online sales are dependant may be drastically different, to the point where one may suggest that the legal nature of some auctions on eBay is also different.

Such differences have started to be acknowledged by legislation in different countries, especially in France and in some American States. For example, in France the Voluntary Public Auctions and Auction Brokerage Act 2000 differentiates between traditional public auctions conducted online and eBay style auctions akin to a form of brokerage. In the USA, many States require a licence to deal as an auctioneer, but some States have adopted legislation to exclude online auctions from this obligation. It is the case in Ohio, where Section 4707.02 of the Ohio Revised Code ${ }^{2}$ excludes from the requirement of obtaining a licence for the conduct of auctions, any "auction mediation company" as well as "a person who sells real or personal

\footnotetext{
${ }^{2}$ Section 4707.02 of the Ohio Revised Code (in Ohio Auctioneer Guide), accessible online: http://www.legislature.state.oh.us/bills.cfm?ID=126_SB_99, [06/02/2006].
} 
property by means of the Internet." The scope of this later exclusion is broad as the Revised code defines a "person" as "an individual, sole proprietor, corporation, limited liability company, association or partnership." In addition, intermediaries such as eBay fall under the classification of "auction Mediation Company" and are also excluded from the scope of traditional auctions. As a result, all online auctions whatever their legal status are excluded from the control of the Ohio Department of Agriculture which administers the auctioneers licensing programme. Such legislation marks a clear acknowledgement that the sales conducted online on sites similar to eBay are not the same as those conducted by traditional auctioneers, even if traditional auctioneers also use the Internet to conduct some sales.

No position has yet been adopted in the UK via statute or case law, and the lack of legal certainty as to the legal regime applicable to online auctions risks jeopardising the protection of consumers dealing on these sites. English law does not possess a statutory definition of auctions nor of online auctions. In the absence of such authoritative definition (1.1), I propose to apply a three-pronged approach in order to ascertain the legal classification of online "eBay" auctions (1.2).

\subsection{The Absence of an Authoritative Definition of the Notion of Auctions}

In the absence of a definition, one has to refer to doctrinal sources as a starting point for discussion. Halsbury's defines auctions as "a manner of selling or letting property by bids, usually to the highest bidder by public competition." (Halsbury's Laws, 1991, para. 901).

This wide definition could a priori encompass the main characteristics of an auction conducted on eBay or other similar sites such as QXL.com, Yahoo!Auctions, or Amazon Auctions. Indeed, auctions conducted on eBay offer a manner of selling property. Items are put up for sale on the site by way of a listing containing details of the sale that is made available to the public. The sales can either be made via an auction format or via a fixed price format. When the auction format is selected, any interested party can register on the site and take part by placing a bid. In addition, and still satisfying the requirement of the Halsbury's definition, the terms and conditions ${ }^{3}$

\footnotetext{
${ }^{3}$ Note that all references to online auction sites' terms and condition refer to the version in application on 09\05\2005 and freely available on the online auction site.
} 
adopted by the site and in particular clause 5.3 dictate that the highest bidder will usually be the winning bidder when the auction period (of 1 to 10 days) comes to an end. The bidding process can involve the interested parties following the auction for its entire duration or using the proxy bidding system, which will automatically increase their bid by increments to avoid being outbid, up to a maximum bid specified. Once the maximum bid is reached, and the bidder remains unsuccessful, a system of email notices will alert the bidder, who can choose to bid further or stop. Through this system of automated bids, the parties are able to compete to place the winning bid, thus satisfying the element of public competition.

However this unrefined analysis seems unsatisfactory for at least two reasons: First, it is based on what some authors deem to be an unreliable definition and second, this classification of auction would not necessarily be in the best interest of consumers.

Christina Ramberg (2002, p. 45, para 4.41) has pointed out, the Halsbury's definition is "both too narrow and too vague to be of any assistance in the task of legally defining the term auction." This is mainly due to the fact that the wording of the definition and in particular the use of the term "usually", fails to provide enough guidance as to the actual scope of the definition. Similar criticisms could be directed at other doctrinal definitions. For example, Benjamin's Sale of Goods (1997, p. 107. para. 2.004) defines auctions as "a sale by competitive bidding, normally held in public, at which prospective purchasers are invited to make successively increasing bids for the property, which is then usually sold to the highest bidder." Or, according to Macleod (2002, p. 339. para. 10.10), “an auction normally involves a sale to the highest bidder by public competition, conducted on behalf of the seller by an agent, the auctioneer." Another criticism addressed to the Halsbury's definition by Christina Ramberg (2002, p. 45, para 4.41) and which would also apply to the above definitions, concerns the fact that such definition only envisages what is known as English auctions, functioning on a system of ascending bids, but does not take into account other auction methods such as the Dutch auction that follows a descendingprice system. This is all the more important because such mechanisms of descending bids are often used on online auction sites, especially by professional sellers trying to dispose of unwanted merchandise in bulk.

Second, if one was to stop the analysis at the Halsbury's definition, online auctions could be considered as traditional auctions with rather unfortunate 
consequences for the protection of consumers. For example, Directive 97/7/EC and the Consumer Protection (Distance Selling) Regulations 2000 exclude "contracts for goods or services concluded at an auction" from the scope of their protection. In this context, should one decide that the Halsbury's definition prevails and encompasses online auction sites operating on the eBay model, one would forego all protection to consumers contracting online at a distance and by way of an auction. Contrary to Harvey \& Meisel (2006, n 1, p. 19), Atiyah, Adams and McQueen (2005, p. 58) and Howells and Weatherill (2005, p. 370), I do not believe that this is a correct interpretation of the Directive and Regulations. It is my view that the Directive and the Regulations only seek to exclude protection for traditional auctions and not auctions as practised on eBay. This is primarily because at the time of the adoption of the Directive such sale method was not yet prominent and was not envisaged during the discussions. The only auction type known at the time was the traditional auction.

Furthermore, it would lead to a rather peculiar situation if the Regulations were to protect the consumer who bought the same item at a fixed price when denying protection to the consumer who chose the auction model. Indeed, as already explained eBay offers tools for items to be sold using different price formats. Whilst many sales on eBay are conducted via auction, others offer the possibility to buy an item at a specified price. Other sales enable to enter an auction with the possibility to win the item instantly and defeat any bidders if a fixed price is offered. In such cases, both consumers would have bought the goods from the same party, simply using a different sale's method and without being aware of the change in legal regime this implies.

The difficulty then lays in differentiating the two: traditional and "eBay" auctions. Despite some obvious flaws, the above doctrinal definitions have the merit of highlighting some of the main characteristics of traditional auctions, key to the classification of online auction processes. It seems therefore appropriate to suggest a "test" to differentiate the two types of auctions.

The Application of a Three-prong Test to Determine the Legal Classification of Online "eBay" Auctions

At least three factors appear to be significant in the determination of a traditional auction: the sale is organised by public competition (1.2.1), the sale involves a relationship of agency (1.2.2) and the sale goes to the best bidder (that is to say the 
highest bidder in an English auction or the lowest bidder in a Dutch auction for example) (1.2.3).

Those factors are also those that different legal regimes, having adopted a legal definition of auctions, impose as pre-requisite. For example, the Civil Code of Quebec, article 1757 states that "an auction sale is a sale by which property is offered to several persons through the intermediary of a third person, the auctioneer, and declared sold to the last and highest bidder."

Public Competition: A Common Trait of Online "eBay" Auctions and Traditional Auctions

Under English law, the notion of public competition is not defined as such but some elements of a definition can be found in s.3 of the Mock Auction Act 1961. Competitive bidding is described as including "any mode of sale whereby prospective purchasers may be enabled to compete for the purchase of articles, whether by way of increasing bids or by the offer of articles to be bid for at successively decreasing prices or otherwise”.

Therefore as Christina Ramberg (2002, p. 49, para 4.60) indicates, “an important factor in determining whether a procedure constitutes an auction is whether in practice it was possible for several bidders to participate," regardless of whether or not in reality many took part. As a consequence, although bidders on eBay and other similar sites are required to register in order to take part, thus restricting the bidding to a limited number of participants, the element of public competition remains satisfied.

This view is reinforced by the findings in the case of Chambre nationale des Commissaires priseurs and Another v. Société NART SAS and Another ${ }^{4}$, where an American auctioneer (with a French subsidiary) offered Internet users the opportunity to take part into a sale of furniture situated in France. This was in contravention to the then existing monopoly of French auctioneers. ${ }^{5}$ The defendant argued that the Internet

\footnotetext{
${ }^{4}$ Tribunal de Grande Instance (District Court) Paris, 3 May 2000, [2001] E.C.C. 24.

${ }^{5}$ Note that since this case was decided, Loi $n^{\circ}$ 2000-642 of 10 July 2000 abolished such monopoly in order to put French law in line with European freedom of movement of goods and services.
} 
auction sale was not a traditional auction as it lacked, amongst other factors, the element of public competition necessary. This was because the sale was restricted to a public, not only having Internet access, but also having registered on the site. The judge considered that it was possible to conclude that the sale presented all the characteristics of a public auction because it was opened to all interested parties. Indeed, in this case the registration process was used only in order to identify the bidders in the same way that obtaining a bidder's board in a physical auction room would have allowed and was thus not able to annihilate the public element of the competition.

But beyond the ability to place bids, the traditional auction model is normally one where a competitive atmosphere is created. As described by Lord MacNaghten in Frewen v. Hays (1912) ${ }^{6}$,"the prices which the public are asked to pay are the highest prices which those who bid can be tempted to offer by the skill and tact of the auctioneer under the excitement of open competition." Since on online auction sites individual bidders do not meet one another, one may argue that the competitive atmosphere is lacking, therefore disqualifying online "eBay" auctions from the scope of traditional auctions. This is what the defendant in the case of Chambre nationale des Commissaires priseurs and Another v. Société NART SAS and Another ${ }^{7}$, also tried to argue. The judge also rejected this argument claiming that online auctions "do create the same atmosphere and heat in the bidding as traditional auctions. The bids are simultaneous in that the participant knows how much has already been offered and can make a higher bid, although he may experience delays caused by the nature of an online auction and the technical demands involved”. Indeed whilst in practice, online "eBay" auctions may last a lot longer (up to 10 days) and perhaps be less intense than their traditional counterparts, the excitement of the competition is still very much alive. Most of the activity in the online auction process takes place near the closing time of the auction as in a traditional auction. In addition, the system of proxy bidding and email alerts enable participants to monitor the progress of the online auction and compete in the race to the winning bid.

\footnotetext{
${ }^{6} 106$ LT 512, PC at 518.

7 Tribunal de Grande Instance (District Court) Paris, 3 May 2000, [2001] E.C.C. 24.
} 
In light of the above one can only conclude that the element of public competition is very much a common characteristic of auctions either online or offline, making it impossible, at this stage, to state definitely whether or not online "eBay" auctions should be considered as traditional ones. However, as far as the UK is concerned, it is important to note the role attributed to the auctioneer in creating the said competitive atmosphere. Lord MacNaghten indeed refers to the skill and tact of the auctioneer suggesting that a third party needs to be involved in the auction process.

The Relationship of Agency: A Key Differentiating Factor Between Online "eBay” Auctions and Traditional Auctions

As noted by Harvey and Meisel (2006, p.29, 1), “an auctioneer is a particular kind of agent," he is one that will represent the principal, i.e. the seller at auction, and have the required authority to affect the principal's legal position in respect of third parties to the relationship, namely bidders at the auction. The auctioneer may also act as the agent of the buyer in its relationship with the seller.

Defining the Relationship of Agency in Online "eBay” Auction Sales

This relationship of agency, under which rights and obligations are attached to the parties, is eloquently described by Lord Denning in Chelmsford Auctions Ltd $v$. Poole ${ }^{8}$ :

"On a sale by auction, there are three contracts. The first is the contract between the owner of the goods (the vendor) and the highest bidder to whom the goods are knocked down (the purchaser). That is a simple contract of sale to which the auctioneer is no party (...). The second is the contract between the owner of the goods (the vendor) and the auctioneer. The vendor entrusts the auctioneer with the possession of the goods for sale by auction. The understanding is that the auctioneer should not part with the possession of them to the purchaser except against payment of the price: or, if the auctioneer should part with them without receiving payment, he is responsible to the vendor for the price (...). The third is the contract between the

\footnotetext{
${ }^{8}[1973]$ QB 542.
} 
auctioneer and the highest bidder (the purchaser). The auctioneer has possession of the goods and he has a lien on them for the whole price."

In online auctions conducted on eBay or similar sites, a tripartite contractual relationship also exists. The vendor contracts with the online auction site for the provision of the technical tools necessary for the advertising and hosting of an auction. Indeed the online auction site provides the required software to assist the seller. It is this software that enables the seller to upload information on the site, conduct the auction and/ or advertise a buy-it-now price. The purchaser also has a contract with the online auction site. This contract is for the provision of the technical tools necessary to access and take part in the live auctions or to proceed with buying items offered with a buy-it-now price. Finally when the auction process comes to an end, a contract can be formed between the vendor and the successful bidder. However, this tripartite relationship should not lead to confusion and to the hasty conclusion that all online "eBay" auctions can be classified as traditional auctions. This is because while there are indeed three parties involved, the parties do not all fulfil the same legal role in traditional auctions and in online "eBay" auctions.

The relationship of agency appears to be the legal relationship upon which the classification of an individual or legal entity as an auctioneer hinges in many jurisdictions. Indeed, in France, the absence of a relationship of agency is one of the major factors differentiating traditional public auctioneers from online auctions of the "eBay type". The Voluntary Public Auctions and Auction Brokerage Act known as Loi $\mathrm{n}^{\circ}$ 2000-642 of 10 July 2000 portant réglementation des ventes volontaires de meubles aux enchères publiques et courtage aux enchères, creates article L 321-3 of the Commercial Code. Paragraph 2 of this article states: "Brokerage operations in computerised auctions, characterised by the absence of a sale by auction and intervention by a third party in the conclusion of the sale of an item of property between the parties, shall not constitute a sale by public auction." The absence of intervention of a third party in the conclusion of the sale is therefore essential to withdrawing online auctions from the scope of sales by public auctions (MaugerVielpeau 2004), whilst if the auctioneer acts as an agent of the vendor, the sale constitutes a sale by public auction. In the Canadian Province of Quebec, article 1757 of the Civil Code also requires the intervention of an auctioneer acting as an intermediary for a sale to be a sale by auction. 
In the UK, s. 57 of the Sale of Goods Act 1979 indicates: "a sale by auction is complete when the auctioneer announces its completion by the fall of the hammer or in any customary manner." This can certainly open the door to online auctions being considered as traditional auctions, the digitisation of the process being unable to alter the classification ${ }^{9}$. However, if one agrees in English law that the physical presence of the auctioneer should not be required, thus enabling traditional auctions to take place online, such person must nevertheless exist, taking on the role imparted by s. 57 of the Sale of Goods Act 1979 and completing the sale by auction.

Harvey and Meisel (2006, p. 17, $\left.\mathrm{n}^{\circ} 1.41\right)$ argue that eBay can be considered "as acting as auctioneers, albeit to a limited extent." This analysis is based on the fact that eBay charges a fee from the seller as well as a commission on successful sales, and that the site also provides advice to the parties, promotes payment protection and dispute resolution. I do not share this opinion and do not believe that the fact that eBay receives payment from the seller or a commission after the sale (which actually comes from the seller and not the buyer as it is normally the case in traditional auctions) means that they have been instructed to affect the legal relationships of the parties. Moreover, the simple provision of software fully controlled by the seller (and not eBay) is not enough to characterise the role of the online auction site as that of an auctioneer. Indeed, eBay does not write the listing nor does it post it online. The site does not control the length of the auction, which is also decided by the seller. In addition, eBay does not take possession of the goods sold via its web site. Such goods remain with each seller. Whilst eBay does indeed provide much information to the parties and describe to some length how best to organise a sale, or participate in one, the advice provided here does not strike us as being equivalent to the advice an auctioneer will dispense. EBay's information is generic, whilst an auctioneer will have a duty to proceed with the sale to the best advantage of its client. Indeed, traditional auctioneers are under a duty to act with skill and care implying that the advice dispensed should be tailored to each seller's particular situation. Finally if eBay does dispense information on payment, it does not at any point handle payments for the parties as a traditional auctioneer would.

\footnotetext{
${ }^{9}$ Thus, whilst s. 57 requires the presence of a third party, Christina Ramberg (2002, p. 50, para 4.67 and 4.71) acknowledges, "there is no need to include a prerequisite of a human auctioneer in the definition of an auction."
} 
Many sites clearly state that they are not considering themselves as agent in the transaction. We have already mentioned clause 3 of Ebay's User Agreement, which states "eBay is not an auctioneer. Although we are commonly referred to as an online auction web site it is important to realise that we are not a traditional auctioneer(...).” Other sites, for example Amazon auctions, also distance themselves from the classification of traditional auctioneers. Their participation agreement, clause 1.5, unmistakably states: “Amazon is not an auctioneer, neither is it an intermediary between the buyer and the seller. Amazon provides a venue for sellers and buyers to negotiate and complete transactions (...) Amazon is not involved in the actual transaction between sellers and buyers and is not the agent of and has no authority for either, for any purpose (...)."

The montage used by online auction sites is that each party is the recipient of a series of services provided by the online auction site. This is comparable to the situation of the owner of a car boot sale or of a classified pages publication. Those intermediaries do not act as an agent for either of the protagonists, buyer or seller. In the UK this position appears to be supported by the Office of Fair Trading, which on its website ${ }^{10}$, in the "Shopping from home" rubric explains that it considers online auctions to fall outside the scope of traditional auctions, advising consumers that "Internet auction is the term commonly used to describe any kind of website that allows people to sell a wide range of goods in a number of ways including through competitive bidding. They do not normally fulfil the functions of a live auctioneer, and therefore the legal obligations of an auctioneer are not likely to fall on them." In addition, the Department of Trade and Industry fact sheet on Internet Auctions explains to consumers that "Internet auction is the term commonly used to describe any kind of website that allows people to sell a wide range of goods in a number of ways including through competitive bidding," but by no means associates online auctions with traditional auctions. The fact sheet clearly explains: "Buying on internet auction sites is similar to buying goods from classified adverts in newspapers." 11 Furthermore, the Department of Trade and Industry and the Office of Fair Trading in a consultation paper (DTI \& OFT, 2005) on the text of guidance for businesses about

\footnotetext{
${ }^{10}$ http://www.oft.gov.uk, [10/10/2007].

${ }^{11}$ DTI, Fact Sheet, Internet Auctions, http://www.dti.gov.uk/ccp/topics1/facts/internetauctions.htm, [13/01/2006].
} 
the Distance Selling Regulations, corroborate this interpretation indicating that "some activities described as auctions may not necessarily result in sales at auctions (...)” and that it depends to a large degree on how the selling process occurs.

Therefore it is in the relationship of agency that online auction of the "eBay type" differ drastically from traditional auctions. Indeed, a typology of online auction sites demonstrates that whilst some entities may indeed act as auctioneers and use the online environment to conclude their sales, others do not take on their role as intermediary to the same degree. The classification as auctioneer therefore depends on the reality of the legal relationship formed between the parties to an online auction and will need to be assessed on a case-by-case basis.

\section{A Typology of Online Auction Sites}

A wide variety of online auction sites is currently in operation in England and worldwide. Whilst the present typology is likely to be rapidly out of date, many models emerging everyday, four main categories can be identified at this moment in time. Each category has a different impact on the position of the consumer and his or hers potential protection. For example, in this first category, the protection of consumers is identical to that granted to consumers in traditional auctions and therefore limited, whilst with other category this protection may range from inexistent to potentially very good if the latest distance selling rules can be applied.

\section{Traditional Auctioneers Using the Internet as an Additional Sales Channel}

First of all, it is possible for traditional auctioneers to sell via a virtual auction room rather than a physical one or use both. New technologies such as video links, 3D imaging and broadband can make this possible. As with telephone bids, it seems that bids placed during a virtual auction could not alter the legal classification of the auction. Indeed, regardless of the technology involved, the auctioneer will retain its role as agent of the parties and therefore may remain a traditional auctioneer. For example in the UK, Gilden's Art ${ }^{12}$ conducts live auctions where bidders can also participate online. Another example is that of the Saleroom ${ }^{13}$. Whilst the Live auction

\footnotetext{
12 http://www.gildensart.com, [10/06/2006].

13 http://www.the-saleroom.com, [10/10/2007].
} 
is taking place in a real physical auction room, registered bidders can listen in and see the items being put up for sale online. Online bids can also be placed in real time. Bids are considered whatever their sources in real time by the auctioneer.

\section{Principals Using the Auction Sale to Simplify Private Treaty Negotiations}

Another category of sites is that of principals offering their products via an auction sale process. This is for example the case of auction4it.com offering electronic equipment, or of the hotel chain Thistle ${ }^{14}$ that, until recently, offered unsold rooms at auction. The contractual relationships forming through those sites clearly lack representation since the vendor acts for himself. Those online auctions should therefore clearly be excluded from the scope of traditional auctions. The auction sale process is simply used as way to replace the private treaty negotiation that would have been conducted by the principal with the different interested parties, thus perhaps ensuring a better price (when there is competition) and simplifying the process of identifying the best offer.

\section{Agents Using the Internet as a Sale Channel}

Thirdly, other sites such as LastMinute.com ${ }^{15}$ are in fact acting as agent. Clause 2 of Last Minute's terms and conditions of auctions indicates indeed, "Except for the sale of a very small number of products (such as, for some entertainment tickets) our Channels operate to an agency model. This means that we act as a disclosed agent for third party suppliers, such as a tour operator, hotel or a restaurant." The clause continues stating that although a contract of sale is concluded directly between the seller and the buyer, the operator may still be liable to the buyer if Last Minute has been negligent, has misrepresented important information or is in breach of any other relevant law. In this instance, it is possible to envisage that such sites may be considered as traditional auctioneers should they also satisfy the other pre-requisite conditions. Yet to some degree, the agent may not always be in possession of the goods. But it seems that in this instance the seller will have intended to give the agent full powers to affect his/ her legal position.

\footnotetext{
14 http://www.thistleauctions.com, [04/07/2006].

${ }^{15}$ http://www.lastminute.com. Note that the site does not appear to conduct auctions any longer, yet still contains terms \& conditions relating to the conduct of auctions on the site, [10/10/2007].
} 
Finally, some sites epitomised by eBay, and upon which this article focuses, are not representing the seller, but simply providing essential tools to conduct sales online via auctions or other processes. Although the sites' operation is similar to that of previous categories, it is clear that such sites only provide the tools necessary to organise an online auction and facilitates its process by providing services such as proxy bidding. Going back to Lord Denning's description in Chelmsford Auctions Ltd v. Poole ${ }^{16}$, the sites' representatives do not at any stage act as an agent for the parties where they would be entrusted with the goods for sale by auction by the vendor or the payment of the price by the purchaser. Indeed, the bidders are not able to pre-inspect the goods (whether or not they wish to do so) under eBay's authority. Buyers and sellers are contracting on the basis of the description and photos provided on the website and are not able to inspect the goods like participants in a traditional auction would normally be able to. EBay also do not have the legal authority required to affect the legal position of sellers using the site. In such case one may conclude that eBay and other similar online auction sites should not be treated as traditional auctioneers since the relationship of agency between the parties is lacking.

One however needs to note that other third parties, acting as agents or even auctioneers, use eBay and other similar sites to sell items by way of an auction. For example, consignors have started to develop a parallel business, using eBay to conduct auctions for third parties. Worldwide Auctions ${ }^{17}$, a business based in Orpington Kent, acts as a drop-off centre. Seller on eBay since 2001, this business benefits from the status of a power seller on eBay, i.e. seller who is maintaining an excellent feedback record of $98 \%$ or more, selling an average of $£ 750$ a month or 100 items per months for three consecutive months. In this case, the drop-off centre has the merchandise in its possession and handles all enquiries, listing, and even receives the payment for the owner of the goods. The drop-off centre even warranties the description of the goods posted on eBay. To our knowledge it is not yet possible to inspect the goods prior, but the practice has started to develop in the USA, where the

\footnotetext{
${ }^{16}$ [1973] QB 542.

${ }^{17}$ http://www.WorldWideAuctions.org, [10/10/2007].
} 
goods to be put up for sale are deposited with the trading assistant and can be available for inspection on location. However, if we could argue that an auction indeed takes place because a consignor acting as an agent takes part in the sale, it is that consignor (either individual or legal entity) that is fulfilling the function of an auctioneer, it is not the auction site itself. So in the case of Worldwide Auctions, whilst eBay is being used for all sales, it is not eBay that could be considered acting as an auctioneer, but Worldwide Auctions. Worldwide Auctions could be classified as an agent using the Internet as a sale channel.

From a UK perspective, considering online auction sites of the "eBay" type outside the scope of traditional auctions appears to be a legally sound conclusion. It may also be one that is supported by Harvey and Meisel (2006, p.17, $\left.\mathrm{n}^{\circ} 1.41\right)$ who accept that Internet auction sites such as eBay may not be auctioneers in the traditional sense with the concomitant duties and rights. Equally, if one looks further a field, some jurisdictions have recognised that operators such as eBay were not to be classified as traditional auctioneers. For example, in Ohio" ${ }^{18}$, an "auction mediation company”, i.e., a “company that provides a forum through the Internet for a person to sell the person's real or personal property via the submission of silent bids using a computer or other electronic device," is not required to obtain a licence, whereas this is a pre-requisite for traditional auctioneers.

However, one may not wish to rush into such classification. Indeed it may actually not be as beneficial to cyber-consumers as first envisaged. Considering the online auction site to be the agent of the vendor and the purchaser could enable unsatisfied parties to find redress directly with the site where the transaction was effected. Indeed, under traditional auction rules, a number of obligations fall on the auctioneer. For example, the purchaser may consider the auctioneer liable for any damage to the goods between the close of the auction and the collection of the goods. Also the auctioneer can be liable for misrepresentations under common law and is responsible for the deposit paid by the purchaser before the close of the sale (Harvey $\&$ Meisel 2006, ${ }^{\circ} 1$, p. 158 -169). In an online environment where vendors can vanish without having delivered the goods paid for, and where parties can be located in

${ }^{18}$ Section 4707.01 and section 4707.02 of the Ohio Revised Code (in Ohio Auctioneer Guide), accessible online:

http://www.legislature.state.oh.us/bills.cfm?ID=126_SB_99, [06/02/2006]. 
different jurisdiction such recourse against an identifiable and financially viable "auctioneer" could prove very useful. Nevertheless, such convenience should not artificially lead to the classification of online auction sites as auctioneers especially since, as we have demonstrated, the key criterion of agency is in fact missing from the relationship developed.

So whilst some sites do clearly assume the role of agents and could, if all criteria are satisfied, be considered as traditional auctioneers, the online auction sites modelled on eBay are unlikely to be considered as traditional auctioneers. We shall however endeavour to strengthen this classification by the analysis of our third criterion, if at all possible.

Sale to the Best Bidder: An Unreliable Criterion to Differentiate Online "eBay" and Traditional Auctions

The third criterion identified as a characteristic of an English auction is that the sale goes to the highest bidder. This means that at the close of the auction, the person who placed the highest bid should be successful and enter into a contract of sale with the vendor. For the Dutch auction, it is the lowest bidder that is considered the best bidder, and therefore proceeds with contracting with the vendor. However, on online auction sites, although this is also the rule, in practice the best bidder does not always necessarily win the auction. The auction process has changed from being a method enabling to determine with certainty, price and the identity of the buyer at the close of the auction, to a process enabling to select a number of interested parties with whom one can then proceed to conclude a contract via private negotiations. A few points need clarification at this stage: the process by which the auction closes and the process by which the winning bidder is identified.

\section{Close of the Auction}

With regard to the process by which the auction closes, in a traditional auction made without a reserve price, s. 57 indicates " $a$ sale by auction is complete when the auctioneer announces its completion by the fall of the hammer or in any customary manner (...)." I have already demonstrated that in online "eBay" auctions, the site is in fact not an auctioneer but a simple intermediary assisting in the completion of the 
sale. One question remains therefore concerning the "fall of the hammer" and whether or not such adjudication must necessarily take place for a sale by auction to occur.

One can indeed object that online auctions are not concluded by the fall of a hammer, thus not being traditional auctions. The hammer, in this case, would only be virtual as a recent case from the German Supreme Court ${ }^{19}$ (Hartwig, 2005) indicates, preventing any completion of the sale. This is at least the position in German law where adjudication must take place for a sale by auction to have effect. In this particular case, the claimant had purchased a diamond bracelet from a third party advertising the auction on eBay. The claimant received the bracelet but on closer inspection refused to pay and claimed it had a right to return the bracelet. The German Supreme Court determined that in application of $\S 156$ of the BGB the fall of the hammer was required in order to conclude the sale, thus the auction taking place on eBay could not be considered within the scope of $\S 156$ of the BGB, but was subject to the application of the rules on distance selling instead allowing the consumer to return the goods.

Under English law however, such a position may not be tenable as s. 57 (1) makes provision for the sale to complete by fall of the hammer or "any customary manner" which may include a set time elapsing without the intervention of any of the parties or their agent. The same outcome seems inevitable in the Canadian province of Ontario where s.56(a) of the Sale of Goods Act indicates that the sale can also be concluded by other customary manner. Therefore, akin to the $17^{\text {th }}$ century process of candle auction, one may consider that online auctions can be concluded via different means than the fall of the virtual hammer. This suggests that online "eBay" auctions could be considered as traditional auctions, if one had to consider this criterion alone.

\section{Identification of the Best Bidder}

The identification of the highest bidder in traditional English auctions without a reserve price takes place via the application of s. 57(1). Under this section, it is understood that the auctioneer formulates an invitation to treat and that each competitive bid constitutes an offer that the auctioneer will accept at the close of the sale, thus forming the contract. If the auctioneer has control of the auction process, he

\footnotetext{
${ }^{19}$ Bundesgerichtshof VIII ZR 375/03, 3 November 2004.
} 
is free to accept or reject any bids, as suggested by Treitel $(1999$, p.11). But since the auction is closed after the last bid has been taken into consideration, this means that necessarily the highest bidder is to be successful in an English auction. When the sale is made with reserve however, section 57(3) SGA 1979, suggests that each bid is converted into a conditional offer. The condition is that, should the reserve price be met, the sale has to go to the highest bidder. In the event of the reserve price not being met, the auctioneer is under no obligation to sell and is free to reject any bids made as he was for sales under s. 57(1). Nevertheless as soon as the reserve price is met, and when bids stop, the highest bidder is to be the winner of the English auction.

The direct consequence of the application of such rules is that at the close of the auction, one knows with certainty the identity of the buyer and the price at which the goods are to be purchased (provided that in a reserve auction, the reserve price has been met). The parties are not permitted to withdraw from the sale without breaching the contract concluded. As pointed out by Laurence Mauger-Vielpeau (2000) a traditional auction offers an objective and automatic method of determination of the buyer and price ${ }^{20}$. Indeed, under an auction format, the person of the buyer and the price are not subjectively chosen via private negotiations. The same applies in other types of auctions, for example the Dutch auction where the best bidder is in fact the lowest bidder.

Online auction sites' terms and conditions mimic such traditional rules. Indeed, clause A2.4.1 of the Amazon Auctions Participation Agreement, indicates for example: "sellers are obliged to accept any bid that meets or exceeds the initial minimum bid or reserve price (if any) and in such case a contract for the sale of the item from the seller to the buyer will form on the closing of the auction." Equally, the QXL terms and conditions under clause 7(a), indicates that "the person who bids the highest price wins - as long as that highest bid is equal to or higher than the reserve price the Seller has set (...).”

However, we must note at this stage, that the obligation imposed on the parties to conclude the contract at the close of the auction sale is only a contractual one and not a statutory one such as that imposed by section 57 of the Sale of Goods Act 1977. Indeed, it derives from the contract that each party to the contract of sale has

20 The French wording is as follows: un mode objectif et automatique de determination de la personne du cocontractant et du prix. 
concluded, not with one another, but with the online auction site. Therefore the question of the privity of contract needs to be raised. In a traditional auction a contract is also concluded between the parties and the auctioneer, but in this case, the agent has the legal authority to commit seller and buyer to the transaction. In "eBay" auctions, this is not the case. The question of privity is especially relevant in transactions where a successful bidder has refused to complete the transaction. Sellers are in this case advised to file a "non-paying buyer alert" on eBay and request a final value fee credit, which in effect, reimburses the commission paid to the site. This reimbursement has the effect of nullifying the auction that took place. Such advice dispensed to sellers seems to suggest that the rules applicable to the formation of the contract by way of an "eBay" auction are not directly enforceable against the buyer.

Some further difficulties arise as online auction sale processes become more and more refined and commercially oriented. Indeed the main reason for pushing the conclusion of a sale is that the site gets its remuneration from the commission earned on completed sales. It is therefore of the utmost importance to the site that as many sales as possible go through and are successfully completed. This explains why online auction sites have developed alternative ways of concluding sales for the less adventurous of their clients. This includes fixed-price sales and processes under which an auction sale is salvaged enabling the site to still accrue its commission.

The first of those difficulties is the practice of an auction sale alongside a fixed price sale opened for the duration of the auction. Indeed, while the auction runs, it is possible for the seller to decide to offer the same product for sale at a fixed price. During the auction process it is possible for anyone to select this option and buy the product for a fixed price, thus putting an end to the auction. For example, QXL's terms and conditions, clause 6(b) indicates that "In some Auctions, Members can alternatively make a Buy Now! purchase. This will only be possible where the Seller has specified the price (we call it the "Buy Now! price") for which he/she will sell the Auctioned Item outright - as an alternative to waiting to sell to the member who has made the highest bid at the scheduled close of the Auction. Thus a Buy Now! "bid" is, in fact, an agreement on the part of the buyer to purchase the relevant Auction Item for the Buy Now! price. It is not a bid which can be exceeded by another person's bid. Indeed, once a Buy Now! bid is made, the Auction for the relevant Item will close (...), and no other Auction bidding on that Item will be possible." Therefore, in such circumstances the best bidder will not necessarily be a party to the contract of sale at 
the close of the auction as it would have been in a traditional auction. This best bidder is altogether sidelined for the benefit of another third party, who did not wish to enter the auction process. In this case, it would be very odd to provide buyers entering the auction process and buyers going for the buy-it-now option two different legal regimes to apply to their transaction. On the one hand, if one considers that the auction process is a traditional auction, one excludes the consumer from the realm of the application of the Consumer Protection (Distance Selling) Regulations 2000, which excludes auctions but would apply to a buy-it-now sale. On the other hand, if one considers online "eBay" auctions to not be traditional auctions, one then allows consumers to be protected equally whatever the mode of sale chosen.

Another of those difficulties is the fact that in some transactions, although there is a best bid, which wins the auction, the contract cannot be completed. Under eBay's User Agreement, clause 5.3, the seller can refuse to complete the transaction with the highest bidder if: "(a) the item is listed in a category under our non-binding bid policy, (b) the buyer fails to meet the conditions of the seller's listing (such as payment method); or (c) the seller cannot authenticate the buyer's identity." The nonbinding bid policy referred to is a policy used by online auction sites under which the bids are not binding offers but simple indications of interest. This concerns properties such as real estate or the sale of a business where the law requires further formalities than a simple exchange of emails at the close of the auction. The last two grounds for refusing to complete the transaction are situations where it is apparent that the buyer is not forthcoming and that not all conditions of sale have been agreed upon. Indeed at the conclusion of an auction, the online auction site will send to the parties an email revealing their identities to each other and prompting them to finalise the sale. This may involve further negotiations on the cost of delivery for example, and arranging payment methods. It is possible at that stage that the buyer will be unable to pay by credit card for example, where the seller required such a payment method. It is not uncommon that the buyer who won the auction, but changed his or her mind, will also remain silent at this stage. Since the buyer is then unable to assert the buyer's true identity and trustworthiness, it is a cause for the seller to refuse to complete the transaction.

In such situations, what are known as second chance offers, can often take place. This is the process under which the vendor, having failed to complete the transaction with the original highest bidder will address to any of the under-bidders of 
its choice an offer to purchase the item that was put up for auction at the price stipulated in the bid. This does not mean that the second highest bidder is necessarily to be offered the second chance and the seller is free to select any of the underbidders. Those situations where a seller cannot be identified, or when a private treaty sale needs to be organised following the failure of an auction, can, from time to time, also occur in traditional auctions. However it seems that one of the main difference reside in the fact that in traditional auctions, it is the auctioneer who proceeds with those difficulties, acting for the seller and not the seller himself. Since eBay does not act as the agent of the seller, eBay or any similar site, will not conduct the private treaty sale. It will be in fact, the seller himself, whether an individual, business or agent that will proceed with identifying the potential second chance buyer and getting in contact to effect the sale.

It appears therefore that the requirement that a sale is going to the best bidder is unreliable to differentiate online "eBay" auctions from traditional auctions, since a party other than the best bidder may ultimately win a sale by auction. It seems that in the case of online auctions as they are practiced on eBay, the designation of the best bidder as the winning bidder is not providing an objective and automatic way of identifying a co-contracting party as well as a price, which characterised traditional auctions. Instead the auction is either used as a mechanism to narrow the number of interested parties, and may make way to private negotiations, or as a means of providing an opportunity for obtaining a better price when the auction process is combined with a fixed price sale.

After applying the three-pronged test, what I hope to have established so far, is that eBay cannot be considered as a traditional auctioneer, as the site does not act as the agent of the seller or any other parties. We have seen that many types of sales can in fact take place on eBay or similar sites. Whilst coined auctions, the sales conducted may not necessarily be so in a legal sense. Such sales will indeed range from buy-itnow sale where the transaction is a simple private treaty sale, to traditional auctions organised by traditional auctioneers or other agents using eBay as a venue. This means that section 5, which excludes sales concluded by way of an auction from the scope of the Consumer Protection (Distance Selling) Regulations 2000, will have to be applied on a case-by-case basis. However this task is extremely difficult because the identity of the parties is kept confidential and is only know by eBay until the close of the auction. This means that consumers buying at an "eBay" auction will not know 
if the Electronic Commerce (Distance Selling) Regulations 2000 will apply to their transaction until it is, in effect, too late. This is detrimental to consumers as it would be difficult for them to fully assess the legal classification of the sale they are about to enter into and the consequences on their legal protection. In addition to this, under Regulation 3(1), only contracts between professionals and consumers are concerned by the Regulations. Sales between consumers or between professionals remain unaffected, although admittedly governed by other laws. Therefore the legal classification of the parties will have a direct impact on the application of the Consumer Protection (Distance Selling) Regulations 2000. However, since eBay's business model is only sustainable if parties rely on the site for communication, users do not know the real identity of the other party until they are committed. The use of pseudonyms makes the identification of the parties rather difficult and as a result, it is almost impossible to really know if the other party is a consumer or a professional before the auction is concluded. Again this will lead to a distributive application of the Distance Selling Regulations, which is damaging to the protection of consumers. It is clear that if one wants to protect consumers, clear information about the transaction, including the protection that derives from the legal regime applicable to it, is essential. By allowing a distributive application of the Electronic Commerce (Distance Selling) Regulations 2000, protection is in fact weakened. Indeed, such distributive application creates complexity and uncertainty. Consumers buying at an "eBay" auction have to combine uncovering the true legal nature of the transaction (traditional auction or distance sale) with establishing the legal classification of the seller, many times to realise that in fact the Electronic Commerce (Distance Selling) Regulations 2000 may not be applicable.

Since it has been established that eBay was not an auctioneer in the traditional sense, one must now uncover the true legal nature of this intermediary and explore the classification of information society services, which governs in the UK, the application of the Electronic Commerce (EC Directive) Regulations 2002.

\section{Online "eBay" Auction v. Information Society Services}

In order to stimulate the development of electronic commerce and more specifically of information society services within the Community, the Electronic Commerce Directive 2000/31/EC of 8 June 2000 established a framework enabling freedom of 
establishment and freedom to provide services online (Recital 5) ${ }^{21}$. One of the main goals of the Directive (Recital 7) is to ensure "legal certainty and consumer confidence by laying down a clear and general framework to cover certain aspects of electronic commerce in the internal market." Its application is therefore of importance for consumers using online auction sites and the protection they can receive. The Electronic Commerce Directive 2000/31/EC of 8 June 2000 was implemented in the UK via the adoption of the Electronic Commerce (EC Directive) Regulations 2002. The Regulations adopt in its Regulation 2(1) the definition of information society services referred to in Recital 17 of the Directive: "any service normally provided for remuneration, at a distance, by means of electronic equipment for the processing (including digital compression) and storage of data, and at the individual request of a recipient of a service.”

One first needs to concentrate on determining if eBay and similar auction sites fall within the scope of the Electronic Commerce (EC Directive) Regulations 2002 (2.1). A positive answer would have two major consequences. It would first of all, trigger the application of rules pertaining to the identification of the service provider and clear communication relating to the contracting process. Such legal classification could therefore lead to a legal environment protective of consumers. Second of all, however, it would also provide cover for eBay as an intermediary. Indeed, under the current regime, information society services benefit from an exclusion of liability in certain circumstances, which is detrimental to the protection of consumers and needs to be reconsidered urgently (2.2).

\subsection{Online Auctions are Information Society Services}

To be classified as an information society service, according to Regulation 2(1), online auctions will need to satisfy three main criteria:

- Be a service normally provided for remuneration (2.1.1); and

- Be a service provided at a distance, by means of electronic equipment; and

- Be a service provided at the individual request of the recipient (2.1.2).

${ }^{21}$ Electronic Commerce Directive 2000/31/EC of 8 June 2000, OJEC L178/1, 17.07.2000. 
It is important to note that the Electronic Commerce (EC Directive) Regulations 2002 as well as the EU Directive do not exclude auctions from their scope. Both are content neutral pieces of legislation and as a result, the classification of information society service could apply to traditional auctioneers as well as principals selling online via auction processes, if the service they provide satisfies the above requirements. This article will concentrate on the service provided by eBay and similar online auction sites only. The second criterion does not cause any particular problems because online auctions of the "eBay type" are undeniably provided at a distance (both parties are not at any stage face-to-face) and by means of electronic equipment (a computer or equivalent equipment is necessary to use the service). One will therefore focus attention on the other two criteria.

\subsubsection{A Service Normally Provided for Remuneration}

As indicated in eBay's User Agreement, clause 3.1, the site offers a "venue which allows registered users to offer, sell, and buy just about anything which is legal, at any time, from anywhere, in a variety of price formats.” The service offered will therefore enable users to offer, sell and buy items. For users selling items, the service will consist in the provision of tools to upload a description of the item for sale and the determination of the sale method, auction or buy-it-now (or both), as well as the provision of the tools to administer the bidding process and the close of the auction or the buy-it-now sale. However for the party wishing to buy or even simply browse, the service consists mainly in making accessible the information uploaded by sellers and enabling bidders to place bids.

The need for remuneration raises issues since the majority of sites do not require a payment from the buyers but only from the successful sellers. Perhaps the only notable exception is the CQout.co.uk auction site, which charges each participant, a fee for registration. Revenue is otherwise generated via the display of advertising, fee on listings, the sale of additional features improving the exposure of an auction sale or allowing the display of a photo of the item and the payment of a commission on the successful completion of the auction. Therefore the service provided to the seller is provided for remuneration since, that person will have to pay a fee for listing the item and, if successful, additional monies for the commission levied. 
However, the buyer does not necessarily receive the service, by which he is entitled to browse through items auctioned and take part, against remuneration. This may impede the classification of online auctions as information society services. Recital 18 indicates that the lack of remuneration is not an obstacle to the application of the Directive. The classification of online auction sites as information society service providers is therefore possible since the notion of remuneration does not necessarily require a payment but is enshrined in the more general notion of "economic activity". Indeed, Recital 18 states: "Information society services span a wide range of economic activities which take place online (...); information society services are not solely restricted to services giving rise to online contracting but also, in so far as they represent an economic activity, extend to services which are not remunerated by those who receive them, such as those offering online information or commercial communications, or those providing tools allowing for search, access or retrieval of data; information; information society services also include services consisting of the transmission of information via a communication network, in providing access to a communication network or in hosting information provided by a recipient of the service(...)." This means that online auction sites do not need to require payment from all parties or indeed any payment at all by the recipients of the service. The service could for example be solely financed by the display of advertising paid for by third parties targeting the audience of users of the online auction site and still satisfy this requirement. This is for example the model adopted by Yahoo!Auctions in the USA ${ }^{22}$.

As a result, online auction sites such as eBay will fulfil this element of the definition and can be classified as information society services providing that the last criterion is also satisfied.

\subsubsection{A Service Provided at the Individual Request of the Recipient}

In the practice of online auction site, the service provided is required by the recipient of the service, be it a consumer or a professional. Indeed, according to article 2(d) of the Directive reproduced in its entirety by the Electronic Commerce (EC Directive)

\footnotetext{
${ }^{22}$ http://auctions.yahoo.com/, [01/12/2006].
} 
Regulations 2002, s. 2(1), the recipient of the service is "any person who, for professional ends or otherwise, uses an information society service, in particular for the purpose of seeking information or making it accessible." A seller on an online auction site does indeed use the service to publicise the information about the sale being conducted and the potential buyer uses it to search information relating to items he or she may be interested in bidding for. Also any browser will use the service to seek information about the different auctions taking place. This differentiates the service from auctions that are offered on television, for example, where the individual cannot select the particular auction he or she may be interested in.

Consequently, the service offered by eBay is provided at the individual request of the recipient and online auction sites can be classified as information society service providers, subject to the Electronic Commerce (EC Directive) Regulations 2002. This means that eBay, in its relationship with its users must comply with the Regulations. The Regulations will also apply to any other services provided via eBay within the scope of the definition of information society services. The Directive was adopted, as indicated in Recital 7, to "ensure legal certainty and consumer confidence" by laying down a "clear and general framework to cover certain legal aspects of electronic commerce." The Regulations reproduce those dispositions, which provide consumers with some useful information. This includes, Regulation 6 regarding general information such as name and geographical address, as well as an electronic address to ensure communications with the service provider can be direct and effective. In addition, service providers must comply with Regulation 7 on commercial communications and Regulations 10 and 11 on online contracting. In particular, under Regulation 11 the provider must provide clear information as to the contracting process and provide consumers with adequate information.

But despite this clear information being provided, the consumer may not be adequately protected on eBay because of the EU and now UK liability regime adopted for information society services providers.

\subsection{Towards a New Liability Regime for Online Auction Sites?}

Online auction sites using the "eBay model" allow users to post information on each sale conducted. This is done, we have seen, without the direct control of the site and may contain misleading information. It can also contain illegal information in the 
form of sale of items subject to intellectual property rights for which the seller has not obtained an authorisation or a licence or the sale of illegal goods such as human organs or drugs. This may cause damage to consumers who decide to buy, influenced by a misleading advert, and/or who buy copies of products infringing intellectual property rights for example. In such situations, considering online auction sites as liable for the information hosted on their sites seems a convenient way of protecting consumers. It offers an identifiable party to seek redress from, in a process where the parties do not have access to one's true identity and are only identified with nicknames so as to protect the online auction site's income stream. This identification issue, or lack thereof, adds to the difficulty of spotting a fraudster, especially since those nicknames can easily be changed, accounts modified or even closed before the end of a sale. As a result, the liability of the online auction site, as intermediary in the contract of sale, is an attractive prospect. It is also attractive because in most instances, the online auction site will be financially viable and able to offer compensation that a fraudster or a small business could not. However, all online auction sites modelled on eBay exclude such liability and clearly state in their terms and conditions that they will not intervene in disputes involving users.

Unfortunately, in accordance with article 14 of Directive 2000/31/EC of 8 June 2000, implemented in the UK via Regulation19 of the Electronic Commerce (EC Directive) Regulations 2002, it is not currently possible to stop any online auction sites abdicating all liability in such a way. Indeed, information society services providers benefit from an exclusion from any liability incurred from the hosting of information under certain circumstances. Such a non-liability regime applies without distinguishing between content types.

Reg 19 states:

"Where an information society service is provided which consists of the storage of information provided by a recipient of the service, the service provider (if he otherwise would) shall not be liable for damages or for any other pecuniary remedy or for any criminal sanction as a result of that storage where-

(a) The service provider- 

and, where a claim for damages is made, is not aware of facts or circumstances from which it would have been apparent to the service provider that the activity or information was unlawful; or

(ii) Upon obtaining such knowledge or awareness, acts expeditiously to remove or disable access to the information, and

(b) The recipient of the service was not acting under the authority or the control of the service provider."

One must further review the current liability regime applicable and its shortcomings when it comes to protecting consumers using online auction sites (2.2.1), then explore moves towards a new liability regime benefiting consumers (2.2.2).

\subsubsection{A Current Absence of Liability of Online Auction Sites Detrimental to the} Protection of Consumers

Under the Regulations and Directive 2000/31/EC, the justification for such an absence of liability is based on the absence of control exercised by the provider. Indeed Recital 42 of the Electronic Commerce Directive 2000/31/EC clearly suggests that the exemptions from liability established only concern activities of mere technical, automatic and passive nature, implying that "the information society service provider has neither knowledge of, nor control over the information which is transmitted or stored." It seems indeed appropriate to consider that it would be impractical for online auction sites to review every single auction or fixed price sale posted on their site, first of all because of volume, but second of all because not having seen the goods, it would be near impossible to judge if an advertisement is misleading or if some goods are counterfeit.

Instead the liability regime is based on fault, triggered when it can be established that the intermediary intentionally or negligently violated the rights of others. Therefore consumers appear not to have any recourse against the online auction site if deceived by an advert or if the goods are not delivered despite being paid for if they cannot establish that the intermediary had knowledge or should have had knowledge of the misleading/illegal nature of the listing. 
In the USA a provision equivalent to Regulation 19 has already been tested in front of the courts. A Federal immunity exists in the form of Section 230 incorporated by Congress in the Community Decency Act and the Telecommunications Act 1996. Section 230 indicates that "no provider or user of an interactive computer service shall be treated as the publisher or speaker of any information provided by another information content provider" and that no State law inconsistent with such section can be applied. In the case of Zeran v. Amercian Online, $I n c^{23}$ the court had held that the plain language used in Section 230 created a federal immunity to any cause of action that would make interactive service providers liable for information originating with a third party user of the service. Applying this precedent, in the case of Lars Gentry v. eBay Inc ${ }^{24}$, concerning the sale of fake sports memorabilia to consumers, the court decided that eBay could not be held responsible for the content placed on its website by its users and third parties. The parties had conceded, for the purpose of the appeal, that eBay was an interactive computer service provider subject to Section 230. The court also noted that the categories under which each listings appeared on eBay were selected by the seller and that the seller also provided the content for each listing. On this basis the court concluded that by imposing liability on eBay would equate to holding eBay responsible for content originating from other parties and treating eBay as a publisher, contrary to section 230. The court therefore found against consumers who had been defrauded on eBay and lead to believe that what they were buying were genuine autographed sports cards. If one agrees that eBay cannot be held liable of all content published by third parties, and the potential burden this would impose on the intermediary, one must also acknowledge the detriment it causes to consumers who use the site. In addition, if the absence of liability seems perfectly justified for intermediaries who do not directly benefit from the illegal activities perpetrated, eBay's position appears different here. Indeed, the site will receive commission even on the sale of counterfeit goods, thus benefiting from illegal activities taking place via its intervention. It should, in my view, be a factor taken into account when considering the liability or absence of liability of online auction sites.

${ }^{23}$ Zeran v. Amercia Online, Ltd (4 ${ }^{\text {th }}$ Cir. 1997) 129 F. 3d 327 (Zeran), cert. Den. (1998) 524 U.S. 937.

${ }^{24}$ Lars Gentry v. eBay Inc. 121 Cal. Rptr. 2d 703 (cal App. 2002). 
Actual and Constructive Knowledge

In the absence of case law defining the scope of the defence more precisely in the UK, one can only speculate as to how well the consumers' interest would be protected by the courts. One can wonder if a judge would interpret the notions of control and of actual or constructive knowledge generously, in order to provide the consumer with strong support, in an environment where it is considered that imposing diverging levels of liability on simple intermediaries would stifle the functioning of the European internal market.

The interpretation of the notion of actual knowledge is guided by Regulation 22 , which states that it is for the court to take into account "all matters which appear to it in the particular circumstances to be relevant." Regulation 22 gives some directions as to what type of circumstances need to be considered and points to:

“(a) Whether a service provider has received a notice through a means of contact made available in accordance with regulation 6(1)(c), and (b) The extent to which any notice includes -

(i) The full name and address of the sender of the notice

(ii) Details of the location of the information in question; and

(iii) Details of the unlawful nature of the activity or information in question."

This means that consumers spotting illegal materials must provide eBay with the precise details of the listing. EBay's liability would only be engaged if, on receipt of this notice in the forms prescribed by law, the online auction site does not act expeditiously to remove or disable access to the information.

However the notion of constructive knowledge is not defined by the Electronic Commerce (EC Directive) Regulations 2002. It is however accepted that the online auction site will be deemed to be "aware of circumstances from which it would have been apparent to the service provider that the activity was unlawful," if a reasonable person, having gathered the same knowledge would have concluded in the illegality of the activity or information. Bainbridge (2004, p. 26) suggests that any information or activity published in a widely read newspaper could constitute constructive knowledge. This view seem supported by some examples in practice, such as the 
media coverage of the sale of a kidney on eBay or the sale of charity concert Live 8 tickets that were followed by the prompt withdrawal of the auction sales and any content hosted on the site. Yet, one cannot only rely on the Press to uncover frauds and other illegal or misleading sales on eBay.

To protect consumers efficiently, one may argue that the notion of constructive knowledge and even that of actual knowledge may need to be extended. In the USA, in the case already cited, Lars Gentry v. eBay Inc, the court rejected the claim that "eBay knew or should have known about the illegal or fraudulent activities but failed to take steps to ensure that they comply with the law." This was on the basis that the application of section 230 pre-empted such liability, as it would once again equate to holding eBay liable for its exercise of a publisher's traditional editorial functions, requiring amending or withdrawing materials. The decision was based on a long string of cases having uniformly rejected such claims.

However, one cannot deny that the total absolution of the intermediary may be shocking when this intermediary provides the venue and benefits financially from the transaction. In the case of eBay indeed, it is clear from the above that transactions are subject to a commission and eBay will collect such fee whatever type of transaction occurred, including fraudulent ones or those where consumers end up out of pocket. In eBay's case, it seems apparent that eBay is aware that frauds and illegal trades take place on the site, although they may not be aware of the exact items that would fit the fraudulent description. Example of spontaneous withdrawal of listings demonstrates that eBay has some control over the content it is hosting. In addition, eBay has a full team dedicated to investigating and monitoring fraud and consumers as well as other users are invited to report any sale that went wrong. Following in the footsteps of the Metro Goldwin Mayer Studios Inc. v. Grokster $L t d^{25}$ decision from the Supreme Court of the United States, it may be possible to argue that eBay should be liable for some frauds and bad sales occurring on the site. In the Grokster decision, Grokster, a P2P software manufacturer, was held liable for the infringing activities of people who used the software to download music illegally on the Internet. The decision was based on the premises that software manufacturers creating new products with the intent to induce users to infringe the rights of others should be held liable. The decision was significant not only for the fact that it was imposing some liability on P2P software,

${ }^{25}$ Supreme Court of the United States, 27 June 2005, N 04-480. 
but also because it moved away from the Sony Betamax ${ }^{26}$ decision, where manufacturer Sony was not held liable for infringing copies made using the VCRs as legitimate use was possible alongside illegitimate use. This new harder line seems to suggest that the threshold for liability of intermediaries in the US is being rethought and that it can be lowered in situation where the intermediary has little control over the content but provides the tools for infringing activities to take place. In effect, it could be argued that like Grokster, eBay provides the necessary tool for frauds to take place and does so knowingly. Indeed, whilst it is the seller who writes the description, this description is then uploaded on the site and promoted by eBay. Some items are even picked and used as bait on the front page of the eBay site. However, one would have to acknowledge some shortcomings in this analogy. First, the Grokster case concerned copyright infringements whereas most eBay fraudulent sales may not. Second of all, it would clearly be difficult to prove that eBay is intending to induce users to infringe the rights of others, whereas in Grokster the site had publicised its intent to take over Napster's customer base, a similar site that was shut down by the courts and that was openly publicising its "piracy" function. Ebay, to my knowledge, does not directly encourage users to break the law but simply provides tools that can be used to do such thing.

As it stands today, the liability regime established by Directive 2000/31/EC and implemented in the UK via the Electronic Commerce (EC Directive) Regulations 2002, for hosting information is detrimental to consumers because it puts the onus on the consumer to discover the illegal or misleading material and request its withdrawal from the site. It also appears, from the brief analysis conducted, that the equivalent regime in force in the United States does no better to provide consumers with assistance. In essence, the very person that should be the object of protection has to also become its enforcer. This is a particularly thorny issue as the feedback system used on auction site, which should provide consumers with warning signs, is not fully reliable. At the end of each "eBay auction" or Buy-it-now sale, parties are required to feedback their experience to the community and rate the service received. Thus indicating which traders are or are not reliable. Such system is not foolproof and a recent study conducted by Nikitkov and Stone (2006), shows that negative feedback is often embedded into positive feedback and difficult to trace. In addition the survey

${ }^{26}$ Sony Corp. of America v. Universal City Studios, Inc., 464 U.S. 417 (1984) 
shows that users are reluctant to provide negative feedback for fear of receiving negative feedback themselves. This means that the rating displaying the level of trust that users have developed for one party or another is in fact not necessarily reflecting the reality. This is without taking into account the growing number of fake profiles artificially created by fraudsters or the occurrence of identity theft, where fraudsters hijack an account.

\section{Lack of Obligation to Monitor Information or Inform Competent Authorities}

But the detriment to consumers does not stop here. It is compounded by the absence of an obligation for online auction sites to take active steps to avoid the hosting of illegal information. Indeed, in accordance with Article 15 of Directive 2000/31/EC of 8 June 2000, providers do not have an obligation to monitor the information, which they store. They also do not have an obligation to actively seek illegal activity taking place on their site. Therefore, whilst a provider may quickly remove illegal content when prompted it does not have to continue monitoring similar types of auctions in the future. This clearly is problematic because even when consumers have uncovered a fraud and reported it to eBay, they cannot rely on the site to strike out future frauds of the same type or even by the same individual account holder. This could be different if one was to consider that a reported fraud gives eBay the constructive knowledge of future frauds being likely to be perpetrated. Yet it is true that if this were the case, it would have an impact on the economic model adopted by eBay and would most likely increase operational costs. It would be fair to assume that additional staff would be needed to help monitor the large volume of sales taking place on eBay. Yet, it could also be seen as a price for doing business. Overall however, it seems that if eBay does nothing to avoid frauds on their website, their growing number will start impacting on the confidence consumers accord to the site. Once this level of confidence is damaged it is likely that consumers may prefer other modes of sales. Thus the market should itself start deserting eBay or other similar sites if it feels it is too unsafe, prompting either the disappearance of the business model, or changes in the business model adopted.

In the UK, the detriment to consumers goes even further since Art 15 (2) of Directive 2000/31/EC which allows Member States to "establish obligations for information society service providers promptly to inform the competent public 
authorities of alleged activities undertaken or information provided by recipients of their services" was not implemented. This leaves providers without a statutory obligation to at least inform competent authorities of any frauds or illegal content detected by consumers and reported to the site $^{27}$. This is worrying as it means that eBay and other online auction sites are not obligated to provide adequate information about frauds to the police or to Trading Standards officers on the basis of the UK's implementation of the Directive. This therefore leaves consumers without a possibly efficient way of striking out some frauds via public enforcement.

\subsubsection{The Need for a New Liability Regime to Protect Consumers Efficiently}

At the time the directive was discussed and adopted, little was known of the auction model developed by eBay. The main focus was placed on providers, which enabled users to access the Internet. Since then many categories of providers have come under scrutiny. In an environment where frauds on online auction sites are on the increase, the current liability regime, we have seen, leaves consumers in a relatively uncomfortable situation. It is the same if the sale simply went wrong without the seller being a fraudster. The absence of liability of intermediaries indeed reinforces online auction providers in their non-interventionist approach and also forces consumers to seek protection elsewhere, not always with great success.

Currently consumers that are victims of fraud or bad sale (this could be an item delivered but not corresponding to description for example or an item which in fact does not perform to standards expected, or simply the consumer being disappointed although the item correspond to the listing) have to rely on the insurance mechanisms offered by the secure payment system PayPal or by their credit card company. This is unsatisfactory, first because it implies that it is the consumer that needs to ultimately bear the cost of insurance and second because the PayPal system does not apply to all sales, only those where: goods are not delivered, goods are 'significantly not-as-described' in the listing, and only to sales of up to $£ 500$. Furthermore many conditions need to be satisfied for the sale to come within the scope of the Paypal's insurance system, often leaving consumers without any recourse

${ }^{27}$ Note however that under the Regulation of Investigatory Powers Act 2000 providers may be placed under a duty to intercept, retain or store information. 
at all. Indeed, conditions apply to the seller, buyer and the type of listing concerned. To benefit from protection, the seller needs to have a feedback of at least 50, and at least $98 \%$ of positive feedback (note however that the system used to calculate this percentage is slightly different from that used on eBay, so a $98 \%$ on eBay particulars, may not be a $98 \%$ as far as Paypal is concerned). The user also needs to be registered in a listed country and the seller must have a verified, premier or business account. The standing of account may change rapidly but the eligibility decision is made at the time of the listing. As far as the listing is concerned, it must be on the eBay website and Paypal must have been selected as a mode of payment. Protection is only granted for tangible items that can be sent through the post, so any other items, cannot benefit from the Paypal protection. Finally the buyer must pay the full price in a single Paypal payment and ensure that the "eBay item" is selected as the payment type and enter the correct item number associated with the payment. This means that a small inputting error on the part of the consumer could jeopardise the protection offered should the sale go wrong. To obtain redress the consumer must also ensure that he or she follows the Paypal dispute resolution process by filing a dispute within 45 days of the date of payment and escalate the dispute to the status of a claim. This again may be difficult, as many fraudsters or unreliable traders will stay in touch for a period of 45 days pretending to encounter some delivery difficulties. Sometimes, therefore the consumer will realise that the sale was fraudulent only after this period of 45 days has expired.

Given the important amounts of money earned by the online auction industry, and in particular eBay ( $\$ 1.44$ billion profit in 2006 worldwide), it would seem appropriate to rethink the liability of intermediaries and reflect on the possible liability of online auction sites at least with regard to recurring frauds. Without wanting to jeopardise the business model adopted, it would seem appropriate to require more involvement of the site to monitor recurring frauds and assist consumers' victims of a fraud (at the very least and victim of bad sales also if at all feasible financially). This seems pertinent especially since eBay publicises actively the fact that frauds are a relatively negligible problem in comparison with their volume of sale. EBay frauds are said to represent less than one transaction out of ten thousand. Considering the site liable for the frauds would therefore, in my view, not 
appear to significantly affect the economic model under which it functions, whilst providing consumers with an important tool in their protection arsenal. ${ }^{28}$

The decision of the German Supreme Court in the case of Rolex SA v. eBay $G m b H^{29}$ goes in this direction. This decision overturned previous decisions including a decision from the Court of Appeal in Düsseldorf in February 2004 which considered that eBay could not be held liable for any sale of fake Rolex watches, identified as such on its site because the intermediary was not in fact aware of the specific listings containing fake items. Rolex was asking eBay to monitor and filter new listings concerning "noble replicas" or "deceptively similar to the original" Rolex watches and stop any such listing from appearing on the eBay.de website. The Court rejected eBay's liability on the basis that one could not impose an obligation to monitor content on the intermediary in application of Sections 8(2), 11(1) (1) and (2) TDG. However the Federal Supreme Court considered that whilst "eBay could not be expected to examine every offer for potential unlawful content, it was nonetheless effectively participating in the sale of pirated goods via the commission it was due." The Court based its decision on Art 14(3) of Directive 2000/31/EC which states that the absence of liability for hosting services shall not affect the possibility for a court of requiring the service provider to terminate or prevent an infringement, nor does it affect the possibility for the member state of establishing procedures governing the removal or disabling of access to information. As a result, the Court decided that eBay ought to prevent not only any specific listing whenever its attention is drawn to it, but also use a filtering software to prevent any further infringement of the same type. There are however some limitations imposed by the court, and the decision is by no means recognition of the full liability of online auction sites. The limitations are as follows:

- EBay cannot be held liable for listings that are infringements to the Rolex trade mark but cannot be spotted by the use of the filtering software.

- Claims against eBay are limited to injunctive relief

- Claims for damages are excluded

\footnotetext{
${ }^{28}$ The author acknowledges that more research is clearly needed in this area to assess the operational costs and its true impact on the business' bottom line and viability.

${ }^{29}$ Bundesgerichtshof (Rolex SA v. eBay GmbH) (I ZR 304/01) Unreported, March 11, 2004).
} 
- EBay is under no obligation to prevent against trade marks infringement. The initial listing would still be for the trade mark owner to bring to the attention of eBay.

Unfortunately, if the decision is going in the right direction to recognise that eBay should take some responsibility in the sales taking place on its site, the scope of this decision is limited and unclear. Indeed, the decision will only apply to listing where the item is listed showing that it is clearly offering a fake for sale. The case concerned items described as noble replicas or deceptively similar to the original. It therefore may not have much impact on sales where the seller does not reveal the true nature of the item. Also, the Court does not provide much guidance as to what type of monitoring/ filtering software will be satisfactory. Indeed, the criteria to be used are imprecise, although the Court did mention low price and the suggestion that an item is a fake.

Recent activity in the USA, in the case of Tiffany (NJ) Inc. v. eBay Inc ${ }^{30}$, seem to also call for a review of the liability of online auction sites. Although the case concerns primarily the protection of Trade Marks, its consumer protection nature cannot be denied. As Bainbridge (2007, p585) explains, "Trade Marks can be seen as serving two main purposes: first, reflecting the fact that a registered trade mark is an item of property, to protect business reputation and goodwill; and, secondly, to protect consumers from deception, that is to prevent the buying public from purchasing inferior goods or services in the mistaken belief that they originate from or are provided by another trader."

The jeweller Tiffany filed a lawsuit against eBay arguing that the online auction site, where many fake Tiffany items are offered for sale, should have a responsibility to police the site to higher standards than just enforcing take down notices under the Digital Millennium Copyright Act. This is because eBay benefits from the frauds by earning commission on the sale of fake items. Whilst the case does not appear to dispute the legal status of online auction sites as service providers (as opposed to traditional auctioneer), the arguments raised by Tiffany clearly show that the degree of liability of such providers needs re-assessing. Tiffany is suing for Trade Mark infringement. The jeweller argues that eBay is both directly and indirectly assisting fraudsters, especially because some sales of fake items have been publicised on the

\footnotetext{
${ }^{30}$ Unreported.
} 
front page of the site. Whilst one may have to wait for the case to conclude (providing that eBay is willing to take the risk of trial rather than settling out of court),

considering the service provider liable for recurring frauds would be, from a consumer's perspective, a step in the right direction.

The wave of protest against eBay's non-interventionist attitude continues also in Europe with the recent lawsuit launched by Harry Potter's writer against the sale of unauthorised copies of the book on eBay. Again, whilst the case again will primarily concern intellectual property rights, it could have a strong impact on the protection of consumers. This current judicial activity demonstrates that whilst eBay and other online auction providers are able to avoid liability under the E-commerce Regulations regime, other avenues are currently being exploited. Yet, it is important to note that findings of liability will have cost implications for eBay and its counter-parts. This may mean an increase in costs, which may jeopardise the business model adopted, resulting in higher prices for consumers. It is therefore important to consider those cases not in isolation but within the broader context of consumer protection policy. The main question will therefore be to find a balance between the interests of the online auction industry, intellectual property rights owners, sellers and consumers.

\section{Conclusion}

This article started indicating that at least three factors were significant in the determination of a traditional auction: the sale is organised by public competition, the sale involves a relationship of agency and the sale goes to the highest bidder. Having considered each characteristic in turn one concluded that if all auctions either online or traditional satisfied the criterion of public competition, the criterion which differentiates traditional auctions and online "eBay" auctions most clearly is the absence of a relationship of agency in the auction process between the site and the seller. Without such a relationship, it seems, the auction process cannot be used as an objective means of determining price and contracting party (the best bidder). I therefore concluded that eBay as an intermediary could not be considered as a traditional auctioneer. However, one had to acknowledge that online "eBay" auctions could be conducted by traditional auctioneers using the eBay site or an equivalent as a venue for their sale. In light of this, one suggested that online auctions of the "eBay type" were, for most, not traditional auctions, but are simple contracts of sale of goods 
concluded at a distance subject to the Consumer Protection (Distance Selling) Regulations 2000. However one also noted that the Consumer Protection (Distance Selling) Regulations 2000 had to be applied distributively to take into account the fact that it only applies to transactions involving a consumer and a supplier. In addition, since auctions are excluded from its scope, the sales that are traditional auctions on eBay would be excluded whilst those that are distance sales would come within its scope. However the anonymity system in place on eBay makes the task of identifying the parties and the type of transaction very difficult, to the point that the consumer's rights are left to chance until the contract is concluded. This lottery is highly detrimental to the protection of consumers and needs to be addressed. Either by taking online auctions conducted on eBay and other equivalent sites within the scope of the distance selling Regulations as it has been done in other jurisdictions, or by clarifying which sales are or not with the scope of the protection.

One then turned to uncovering the true legal nature of online auction sites and demonstrated that they could be classified as information society services. Whilst online auctions sites are indeed information society service providers, one had to deplore that this legal nature is not without serious consequences for the protection of consumers. One of the major consequences of this legal classification is the application of the E-Commerce Directive 2000/31/EC of 8 June 2000 which provides online auction sites with immunity from liability for the content hosted on their site and from having to actively research illegal content. This, I explained, needs to be urgently revisited. Current jurisprudential activity seems to show the way for the liability of such intermediary to be reconsidered, if not on the basis of the ECommerce Directive 2000/31/EC, at least using intellectual property law infringements to combat the detriment to consumers caused by fraudulent items. Whilst this is only an emerging trend, I place high hopes on the cases that will emerge in the future, and on the market, which will ultimately push for changes in the business models and liability regimes of online auction sites not corresponding to consumers demand.

\section{References}

Atiyah, Adams \& McQueen (2005). The Sale of good. Harlow: Longman.

Bainbridge D. (2004). Introduction to computer law. Harlow: Longman

Bainbridge D. (2007). Intellectual property. Harlow: Longman 
Benjamin (1997). Sale of goods. London: Sweet \& Maxwell

DTI \& OFT. (2005). A guide for businesses on home shopping. Consultation on the text of guidance for businesses about the distance selling regulations.

OFT698cons. London: Department of Trade and Industry and Office of Fair Trading.

Halsbury's Laws of England (1991, $4^{\text {th }}$ edn Reissue). London: Lexis Nexis

Harvey B. W. \& Meisel F. (2006). Auctions law and practice, Oxford: Oxford University Press

Hartwig H. (2005). Online auctioning between mark and consumer protection, E.I.P.R. 2005, 27(9), 319-326.

Howells G. \& Weatherill S. (2005). Consumer protection law. Aldershot: Ashgate Macleod J. (2002). Consumer sales law. London: Cavendish

Mauger-Vielpeau L. (2000). A propos des ventes aux enchères par internet, Dalloz. $\mathrm{n}^{\circ} 16, \mathrm{p} . \mathrm{V}$.

Mauger-Vielpeau L. (2004). Le courtage en ligne de biens culturels, Dalloz. Chron.. p. 2482

Nikitkov A. N. \& Stone D. S. (2006) Online auction deception: A forensic case study of an opportunistic seller, available online from http://www.bus.brocku.ca/faculty/documents/Online_Auction_Deception.pdf, [31/01/2007].

OFT Market Study (2007). Internet Shopping. London: Office of Fair Trading Ramberg C. (2002). Internet marketplaces, the law of auctions and exchanges online. Oxford: Oxford University Press

Treitel (1999). Law of contract. London: Sweet \& Maxwell 